\title{
GOŚCIE W PRACOWNI OLGI BOZNAŃSKIEJ: VIKTOR E. VON GEBSATTELI I ALFRED WICKENBURG Z PAULĄ MORDERSOHN-BACKER W POBLIŻU*
}

Kolejne pracownie Olgi Boznańskiej jako przestrzeń twórczości i ważny temat jej obrazów są od dawna przedmiotem refleksji badaczy ${ }^{1}$. Rocznicowe wystawy jej malarstwa w Muzeach Narodowych w Krakowie i w Warszawie (2014/2015) oraz towarzyszące im katalogi wieloaspektowo poszerzyły wiedzę o jej osobnym, choć przecież przez wiele lat bynajmniej nie samotnym życiu, a także o tych wątkach twórczości, w których motywy pracowniane są istotne (Bobrowska; Higersberger 16-25). Ów temat przez odniesienia materialno-przestrzenno-czasowe idealnie łączy dwie nierozerwalne kwestie, które czasem metodologicznie bywają rozdzielane: życia i twórczości artysty. Uwieczniona $\mathrm{w}$ obrazach przestrzeń tworzenia to element autoprezentacji artysty, widoczny ,przy okazji” jako tło portretowanych modeli lub zasadniczy przedmiot kompozycji malarskich, środowisko interakcji z zaproszonymi gośćmi (przyjaciółmi, znajomymi, pozującymi i kupującymi), a także z sąsiadami w codziennych spotkaniach mimochodem. Pracownia ma konkretny adres (w przypadku Boznańskiej, jak i innych malarek w Paryżu, nierozłączny z miejscem zamieszkania) podlegający społecznej ocenie. Adres „lepszy” lub „gorszy” określa status lokatora/ lokatorki ze względu na cenę

Dr hab. DoRota KudeLsKa, prof. KUL - Katolicki Uniwersytet Lubelski Jana Pawła II, Wydział Nauk Humanistycznych, Instytut Nauk o Sztuce, Katedra Historii Sztuki Średniowiecznej i Nowożytnej; e-mail: dorota.kudelska@kul.pl; ORCID: https://orcid.org/0000-0002-3408-2812.

* Tekst powstał w ramach grantu NCN: Polscy artyści $w$ Wiedniu: edukacja i udziat w wystawach 1726-1938 (Akademie der bildenden Künste, Kunstgewerbeschule, Künstlerhaus, Wiener Secession, Hagenbund, Galerie Miethke i Galerie Pisko), UMO-2015/17/B/HS2/01683, oraz $\mathrm{z}$ funduszy badawczych KUL.

${ }^{1}$ Bibliografia tekstów dotyczących Olgi Boznańskiej, w których wątek pracowni artystki zajmuje istotne miejsce, w publikacji Agnieszki Bagińskiej U Olgi Boznańskiej. Oblicza pracowni artystki (tu także wybór wspomnień dających najwięcej informacji o atelier artystki). 
domu lub najmu w danej dzielnicy, atrakcyjność towarzyską sąsiedztwa osób i dookolnych ulic (kawiarni, barów, pracowni innych plastyków) ${ }^{2}$. Centrum paryskiego świata Boznańskiej, jak dla wielu artystów osiadłych w stolicy świata sztuki w tym czasie, była dzielnica Montparnasse. W jej obrębie kilkakrotnie zmieniała miejsca, by w 1906 r. ostatecznie osiąść pod adresem Boulevard du Montparnasse 49 (il. 1), gdzie mieszkała do końca życia. To o tym atelier Boznańskiej najczęściej opowiadają zaprzyjaźnieni bywalcy, liczne fotografie i jej własne obrazy ${ }^{3}$. W literaturze przedmiotu, na podstawie wspomnień Polek i Polaków oraz artykułów w rodzimej i zagranicznej prasie, podkreślany jest wielonarodowy charakter kontaktów malarki. Następnie zazwyczaj wymieniani są głównie polscy i francuscy przybysze, a bliżej są omawiane jedynie kontakty artystki z rodakami. Niezwykle rzadko pojawiają się w tym kontekście dokładniejsze informacje o rodzaju kontaktów Boznańskiej z osobami innych narodowości, nawet jeśli są to bohaterowie jej portretów, tak ważni dla europejskiej kultury jak Émile Verhaeren. O tym, że warto poszerzać poszukiwania, świadczą stosunkowo niedawne ustalenia Magdaleny Knapowskiej-Niziołek dotyczące kilkakroć portretowanej wiedenki, pianistki Fridy Eissler (Knapowska-Niziołek). Wspomniana selektywność badań i analiz dotyczy także słabego rozpoznania pozapracownianych kontaktów artystki, takich, które nie skutkowały namalowaniem portretu. Jest to spowodowane trudnościami w dostępie do materiałów oraz dominantą eksploracji francuskich kontekstów twórczości Boznańskiej (z solidnym aneksem do etapu monachijskiego), co oczywiste wobec życiowych wyborów artystki i niezwykłego znaczenia Paryża w kulturze. Nie jest to jednak zwykła przewaga, a przewaga miażdżąca, co niewątpliwie wynika także z zaniedbań badawczych. Szersza analiza tego, jakie dzieła malarka mogła widzieć poza stolicą Francji, pozwoliłaby na dostrzeżenie związków jej obrazów ze sztuką tak mistrzów dawnych (innych niż tylko Velasquez), jak i nawiązań do sztuki współczesnej, powstającej i prezentowanej poza Paryżem, szczególnie w miejscach, które odwiedzała. Niestety brak geograficznego rozszerzenia $\mathrm{w}$ opracowaniu wizyt i kontaktów artystki w Wiedniu, Brukseli i Berlinie ${ }^{4}$. W literaturze przedmiotu pomijana jest nawet dostępna w Polsce liczna niemieckojęzyczna część zasobu archiwaliów Boznańskiej.

\footnotetext{
${ }^{2} \mathrm{O}$ pracowni jako wielorakiej przestrzeni autoprezentacji artystów i artystek w XIX wieku zob. we „Wstępie” do Bagińska (9-18); tu polska bibliografia przedmiotu.

${ }^{3}$ Wieloaspektowość tego wątku omawia Agnieszka Bagińska; szczególnie interesujący jest fragment o pracowni jako „miejscu wyłączonym” (41-45).

${ }^{4}$ Znaczenie wiedeńskich kontaktów Boznańskiej, tamtejszych wystaw, pobytów i przejazdów zob. Kudelska; tekst nie wyczerpuje zagadnienia wiedeńskich związków artystki.
} 
Celem niniejszego artykułu jest omówienie jednego z takich właśnie „niefrancuskich” i „nieportretowych” kontaktów artystki, choć mających miejsce w Paryżu. Świadczą o nich dwie wzmianki w niedatowanym zeszycie Alfreda Wickenburga (1885-1978), który można określić mianem [Wspomnień] ${ }^{5}$. Tekst pozwala domyślać się, że wizyta, jaką autor złożył Boznańskiej z Emilem von Gebsattelem (1883-1976), była spowodowana chęcią obejrzenia jej prac i wymiany myśli. Jak pośrednio wynika z notatki, z Gebsattelem artystka miała jakiś kontakt już wcześniej, a zważywszy na jego zainteresowania, możliwe, że prowadzili interesujące dla obu stron rozmowy o roli i rodzajach postrzegania w sztuce. Był to bowiem z pewnością wyjątkowy $\mathrm{w}$ tej materii interlokutor.

Gebsattel po raz pierwszy przyjechał na kilka miesięcy do Paryża w drugim semestrze roku akademickiego 1902/1903, słuchał wówczas wykładów Henri Bergsona i „całe lato studiował historię sztuki” oraz oglądał muzea (Scheible) ${ }^{6}$. Prelekcje wybrał zgodnie ze swoimi zainteresowaniami, które niebawem upublicznił w doktoracie. Bergson od rozprawy Materia i pamięć. Esej o relacji ciała $i$ umystu rozważał związki ciała, pamięci i umysłu. Filozof uważal, że pamięć, także pamięć materii, sposoby jej przejawiania się w umyśle to zjawisko głęboko duchowe, wprowadził też rozróżnienie czasu obiektywnego i czasu przeżywanego - czasu psychologicznego (Bergson). W 1903 r. Gebsattel uczęszczał zapewne na wykłady o metafizyce i duchowości, prowadzone przez Bergsona w Collège de France ${ }^{7}$. Poznawszy paryskie muzea, wrócił do Monachium, gdzie skończył studia filozoficzne i w 1906 r. celująco obronił doktorat. Jego wybitną pracę Bemerkungen zur Psychologie der Gefühlsirradiation (Uwagi o psychologii napromieniowania emocjonalnego) wydano niecały rok później drukiem (Gebsattel, Bemerkungen). Owo napromieniowanie rozumiał jako „zjawisko polegające na przenoszeniu uczuć z jednego obiektu, który początkowo je wywołał, na inne formy”, badał impulsy afektywne, rozumienie pojęcia „uczucie” i jego kategoryzacje według jakości, intensywności, rozkładalności i w aspekcie progresji czasowej, zdolnej zmienić obraz/pamięć. Obserwacja, jej różne

\footnotetext{
${ }^{5}$ Tłumaczenia wszystkich cytatów ze [Wspomnienień] Wickenburga - Dorota Kudelska. Za informację o zapisie dotyczącym Boznańskiej dziękuję dr Kerstin Jesse, kuratorce Zbiorów XX wieku w Muzeum Belvedere w Wiedniu. Według Jesse tekst powstał przed rokiem 1945. W Museum Belvedere znajduje się archiwum artysty i ośrodek badań nad jego twórczością: Wickenburg: Online-Werkkataloge. Zob. też: Rollig i Jesse; Rollig, Huemer i Husslein-Arco.

${ }^{6}$ Tłumaczenia wszystkich cytatów z tej publikacji - Dorota Kudelska; o ważnym miejscu myśli Gebsattela w historii psychologii w perspektywie filozoficzno-antropologicznej zob. Buda 4-9.

${ }^{7}$ Klarowny porządek tematyki wykładów i kontekstowe omówienie publikacji Bergsona zob. Lawlor.
} 
indywidualne rodzaje były tu podstawą refleksji o postrzeganiu, także postrzeganiu optycznym (Scheible 29 n.). Kilka lat później, kierując się zainteresowaniem antropologią i psychologią, Gebsattel brał udział w Kongresach Psychoanalitycznych, podczas których poznał Zygmnta Freuda, Karla Junga i Lou Andreas-Salomé. Po skończeniu medycyny prowadził z powodzeniem lecznicę i sanatorium dla nerwowo chorych w rodzinnym Schloss Fürstenberg, które skonfiskowali hitlerowcy (Scheible 42, 43, 63-65, 104-107).

W omawianym czasie młody intelektualista krążył po Europie w poszukiwaniu wiedzy: „Po doktoracie [...] Gebsattel prowadził życie prywatnego uczonego, odbywał liczne podróże, szukał i znajdował kontakty z najważniejszymi kręgami europejskiego życia intelektualnego" (Scheible 138). Zakres zainteresowań Gebsattela około 1907 r. i charakter jego obserwacji, jak się wydaje, był bliski także Oldze Boznańskiej.

Z kolei Adolf Wickenburg był wówczas po monachijskiej szkole Antona Ažbego, podjął naukę malarstwa u Jeana-Paula Laurensa (Académie Julian), a następnie (do 1909 r.) studiował w akademii stuttgarckiej (u Christiana Landenbergera i przede wszystkim u Adolfa Hölzela). Od początku był ekspresjonistą, analizującym równolegle energie brył i koloru. Najpierw eksplorował tematy i formy bliskie nurtowi, w którym odnaleźli się także twórcy z grupy Ekspresjonistów Polskich, w późniejszych latach skłaniał się ku dwuwymiarowości, ale pozostała intensywność wyraźnie ograniczonych plam, czasem konturowanych grubą czarną linią, w czym jest podobny do niektórych ujęć Hölzela. Później wystawiał w Wiedniu, a ostatecznie osiadł w Grazu, gdzie pracował jako nauczyciel gimnazjalny, potem jako profesor Landeskunstschule (pracownia pejzażu i martwej natury) i jako asystent w Landesfreskoschule (projektował też witraże, w tym monumentalne, abstrakcyjne kompozycje całościenne - il. 2).

[Wspomnienia] Wickenburga przypominają strumień świadomości przebiegający lata nauki, podróży i pierwszych doświadczeń artystycznych. Autor poświęcił kilka zdań wizycie w pracowni Olgi Boznańskiej. Ze względu na charakter zapisu nie wiadomo, jaki dokładnie dystans czasowy dzieli wydarzenia i czas zapisu, z pewnością nie są to wspomnienia „u kresu życia”. Raz po raz pojawia się praesens historicum, co dodatkowo miesza perspektywy i minimalizuje różnice czasu między zdarzeniami zagęszczonymi we wspomnieniu bardzo ważnego dla narratora okresu życia, czasu artystycznego i intelektualnego rozwoju. Wickenburg zanotował:

\footnotetext{
${ }^{8} \mathrm{Z}$ prac Gebsattela często pojawia się w literaturze Imago Hominis: Beiträge zu einer personalen Anthropologie.
} 
Tej zimy [1907 r. - D. K.] w Paryżu pojawił się także przyjaciel z mojego roku w Monachium, Emil von Gebsattel. Genialnie utalentowany młody człowiek, który ukończył już różnorodne studia, ale nie podjął jeszcze decyzji o stałej pracy. Tylko trochę starszy, duchowo stał znacznie wyżej ode mnie, był także znacznie bardziej dojrzały jako człowiek (...). W krótkim czasie Gebsattel poznał [w Paryżu] wiele ważnych osób dzięki wielu rekomendacjom (...). Mianowicie Rilkego, który jako sekretarz Rodina mieszkał w Hôtel de Biron przy rue de Grenelle i z którym prowadził długie rozmowy, o których czasami wspominał $\mathrm{w}$ naszych rozmowach. Został też przyjęty przez André Gide'a, który właśnie zamówił u Bonnarda malaturę swojego gabinetu, spotkał Paulę Becker-Modersohn, wrażliwą polską portrecistkę Olgę Božnanską [sic! - D.K.] i zjadł obiad z hrabią Kesslerem w piwnicy Vollarda. (Wickenburg, [Wspomnienia])

Intelektualny i towarzyski przewodnik Wickenburga w glorii dobrze zapowiadającego się uczonego korzystał z rekomendacji artystycznych i kulturalnych kręgów Monachium, Berlina i Wiednia, co pośrednio służyło także malarzowi, chociaż nie wiadomo, czy dostąpił też zaszczytu biesiadowania w słynnej piwnicy pod galerią Vollarda, najważniejszego marchanda sztuki nowoczesnej. Kilka lat potem należał do grupy artystów i ludzi kultury „zgromadzonych przez hrabiego Harry’ego Kesslera w Weimarze, zalążku późniejszego Bauhausu, podobnie jak malarz Slevogt, poeta Hofmannsthal i rzeźbiarz Rodin [...]"9 (Scheible 138).

Nie wiadomo, kiedy i jak Gebsattel poznał malarkę, czy i kto jej go polecił. Znajomość trwała dłużej, ale tej kwestii nie wyjaśniają też późniejsze listy Gebsattela do Boznańskiej (z lat 1908-1912) ${ }^{10}$. Skoro jednak zaprosił młodego austriackiego malarza do jej pracowni, to można przypuszczać, że był tam już niejednokrotnie i czuł się na tyle swobodnie, by przyprowadzać kolejnych gości. To jednak spotkanie, zważywszy na wspomniane zainteresowania Gebsattela estetyką i sztuką oraz przede wszystkim, jakbyśmy dziś powiedzieli, teorią percepcji w psychologicznej analizie wrażeń i personalnej pamięci kształtów, subiektywnością spojrzenia podważającego nierozerwalność związku realizmu z obiektywnością form, nie było przypadkowe. Tę różnorodność możliwości rozwoju swego wybitnie zdolnego przyjaciela trafnie dostrzegł Wickenburg. Jego autorytet spowodował, że dla malarza Boznańska, choć pojawia się tylko w krótkim zapisie, to osoba

\footnotetext{
${ }^{9}$ Henry von Kessler (1868-1937), wówczas dyrektor weimarskiego Museum für Kunst und Kunstgewerbe, w polskim piśmiennictwie zazwyczaj występuje nie jako tuz europejskiej kultury, a tylko jako współwięzień Józefa Piłsudskiego i dyplomata.

${ }^{10}$ Listy E. Gebsattela do O. Boznańskiej, Dział Rękopisów Muzeum Narodowego w Krakowie, Archiwum Olgi Boznańskiej. Korespondencja od różnych osób, MNK VIII-rkps-1062/158/1-84.
} 
równie ważna co inne wymienione znakomitości, pamiętana po kilku latach.

Młodzi mężczyźni odwiedzili Boznańską z pewnością we wspomnianej pracowni przy bulwarze Montparnasse 49. W opisywanym atelier Boznańskiej nie było jeszcze zniszczonych sprzętów jak w późniejszych czasach, kiedy zagościły tam myszy (il. 3). Wickenburg znotował:

U panny Boznańskiej, do której pracowni Gebsattel mnie zawiózł, zobaczyłem kilka jej pięknych, pointylistycznych obrazów, które choć [były] raczej ciemne, mieniły się opalizująco. Ona sama była piękną starszą damą, ciemno ubraną, o pięknych czarnych oczach i bardzo bladej twarzy, bardzo przyjazną w kontaktach.

$\mathrm{W}$ pozbawionym ozdób studiu od razu poczuliśmy się jak w domu, miała całkiem niezłe atelier. (Wickenburg, [Wspomnienia $]$ )

Te zdania w jakimś stopniu uzupełnia o trzy lata późniejszy, zupełnie jednak inny w charakterze opis pióra Henryka Zbierzchowskiego:

Choć tym razem drzwi pracowni otwiera mi nie szorstki i nieufny zawsze malarz w poplamionej bluzie i z rozwichrzonym włosem, lecz kobieta z miłym i pełnym wdzięku uśmiechem wkracza wraz ze mną w królestwo czystej i pięknej sztuki.

Przez surowe, ciężkie, olbrzymie wrota wchodzimy do pracowni Olgi Boznańskiej. Niezwykłych rozmiarów pokój ze szklanym dachem, urządzony skromnie i prosto. Fortepian, stare biureczko, parę foteli, piec i stalugi - oto całe jego urządzenie. Dużo światła i przestrzeni, nastrój surowy i skupiony. To nie buduarek modny, ani nie wdzięczne mieszkanko panieńskie, ale naprawdę warsztat malarski, pokój gdzie się pracuje dużo i sumiennie, sanktuarium wysiłków duszy twórczej. I gdyby nie kwiaty świeże, których pęki całe wyglądają ze wszystkich kątów, nie poznałbyśs, że to mieszkanie kobiece.

Półmrok zalega już wielką przestrzeń pracowni. Z półmroku tego wynurza się ku mnie z ręką wyciągniętą postać mała, o zmęczonej nieco twarzy, o oczach jasnych i rozumnych, które umieją patrzeć w duszę. To Boznańska. Taką ją sobie wyobrażałem. Skromna, skupiona w sobie, cicha. Jak duch snuje się po pracowni, z której spoglądają niby niezapomniane miraże, mgliste, zamyślone, lub rozmarzone oblicza jej portretów i studyów. (Zbierzchowski 804)

Zbierzchowski, mimo że traktuje Boznańską jak znaną artystkę, posługuje się stereotypem, przewiduje, czego można „spodziewać się po kobiecie”. Protekcjonalny schemat wyraża zaskoczenie, że czterdziestopięcioletnia malarka nie przyjmuje dziennikarza mającego z nią rozmawiać o sztuce w „buduarku modnym” lub we „wdzięcznym mieszkanku panieńskim”. Poza tym, mimo że jest artystką, ma cechy dobrze widziane u kobiety - jest pracowita, gościnna, dba o estetykę miejsca, ma miłe obejście, jest „skromna, skupiona 
w sobie", cicha, wreszcie drobna, co także odróżnia ją od znanych karykatur wszelkich emancypantek malarek - jak w znanej ilustracji Bruno Paula Malweiber dla Simplicissimusa ${ }^{11}$. Dziennikarz podaje kilka konkretnych informacji o wnętrzu: pracownia jest wielka i dobrze oświetlona (także z góry), wyposażona tylko w niezbędne sprzęty, ale obrazom Zbierzchowski poświęca niewiele uwagi, kurtuazyjnie docenia portrety (,niezapomniane miraże"), ale z enigmatycznych określeń odnoszących się do specyficznej faktury i kolorystyki („mgliste”) trudno wnioskować o malarskiej specyfice.

Wickenburg traktuje artystkę poważnie, pisze o niej jak o damie, nie wprowadza stereotypów myślenia o samotnie żyjących malarkach. Informuje o stylistyce obrazów (piękne, pointylistyczne, mimo że „raczej ciemne, mieniły się opalizująco"). Podziw Wickenburga dla dzieł Boznańskiej bynajmniej nie wynika z podobieństwa jego artystycznych dróg. Zaledwie dwudziestotrzyletni Austriak ani wówczas, ani na żadnym późniejszym etapie twórczości nie podążał stylistyczną drogą Boznańskiej, operującej rozedrganiem delikatnej palety barw i struktury powierzchni obrazów. Ten krótki zapis poświęcony artystce niewątpliwie świadczy o wielkim zainteresowaniu tak dla jej dzieł, jak i dla niej jako osoby. Zapewne, jak wynika z przytoczonych okoliczności, podobne nastawienie miał Gebsattel, skoro zdecydował się zapoznać przyjaciela z niezwykłą gospodynią tego miejsca i pokazać mu jej postimpresjonistyczne, pointylistyczne dzieła.

Najbardziej zaskakujące jest końcowe zdanie cytowanych wspomnień Wickenburga o Boznańskiej: „Była bliską przyjaciółką Becker-Modersohn, malarki z Worpswede, która mieszkała wówczas w Paryżu" (Wickenburg, [Wspomnienia $]$ ).

Nawet o znajomości między tymi artystkami, a cóż dopiero o przyjaźni, między nimi nie wspomina żadne opracowanie dotyczące Boznańskiej. Nie ma też o tym żadnej wzmianki w zachowanych i opublikowanych Listach i dzienniku Pauli Becker-Modersohn (Modersohn-Becker; Beuys; Perry, Paula Modersohn-Becker; Women artists). Z jej zapisów wynika, że zimą 1907 r. niemiecka malarka nie mieszkała już w Paryżu. Kilka miesięcy wcześniej - w ostatnich dniach marca 1907 r. (o czym świadczy datacja w jej korespondencji) - wróciła z mężem, malarzem Otto Mordesohnem, do słynnej malarskiej kolonii artystycznej Worpswede.

Wprawdzie Wickenburg nie daje żadnego uzasadnienia dla cytowanej informacji o znajomości Boznańskiej i Becker, ale jest kilka pośrednich argumentów, które czynią ją więcej niż prawdopodobną.

\footnotetext{
${ }^{11} \mathrm{Na}$ temat kpin z kobiet artystek zob. Arno 56-59.
} 
Po pierwsze, Wickebburg opisuje w tym samym sprawozdawczym stylu wszystkie paryskie wędrówki artystyczne. Nie ma w tych relacjach ani przesady, ani oczywistych pomyłek czy egzaltacji. Różnica ilościowa dotyczy tylko Rilkego, tym kontaktom poświęca więcej uwagi ze względu na zainteresowania artystyczne poety.

Po drugie, Paula Becker pojawia się jako naturalne skojarzenie łączące dwie osoby, wspomnienie o niej pozwala w narracji płynnie przejść od informacji o Boznańskiej do Rilkego, z którym malarz był wtedy w bliskich kontaktach, poznał jego osobiste przeżycia i twórcze dylematy. Artyści zwiedzali razem słynną pośmiertną wystawę Paula Cézanne'a (otwarta 22 października 1907 r. $^{12}$ ) i wiele o niej później rozmawiali. Przy tej okazji Wickenburg relacjonuje wspomnienia Rilkego dotyczące jego kontaktów z Paulą Becker. Wiele mówi o niezwykłym dla poety doświadczeniu wspólnego z malarką oglądania jakiejś wcześniejszej wystawy prac mistrza. Autor Elegii duinejskich podkreślał, jak wielkie znaczenie miały dlań opinie przyjaciółki na temat tego malarstwa. Wickenburg konstatuje, że to Becker „dała mu zrozumienie nowo odkrytego Cézanne'a”, co zaowocowało w ówczesnej korespondencji poety z żoną Clarą Rilke-Westhoff ${ }^{13}$. Pisane wówczas, a wydane drukiem dużo później listy Rilkego Wickenburg skomentował:

Piękne listy do żony, w których od czasu do czasu [Rilke] omawia, z wyjątkową empatią wśród pisarzy, logikę struktury kolorystycznej obrazów z wystawy Cézanna, były niewattpliwie owocem jego obcowania z Paulą Becker. (Wickenburg, $[$ Wspomnienia $])^{14}$

W omawianym kontekście istotna jest zgodność relacji Wickenburga z treścią listu malarki do Rilkego, wysłanego już z Worpswede, po ostatecznym wyjeździe z Paryża. Becker także wspominała ową wspólnie przeżywaną wystawę płócien twórcy Wielkich kapiących się i śledząc z daleka paryskie aktualności i zapowiedzi, bardzo gorąco polecała Rilkemu zobaczenie wspomnianej, planowanej na październik wystawy mistrza w Salonie

${ }^{12}$ [Cézanne], Catalogue. Pokazano wówczas równocześnie trzy wystawy retrospektywne $\mathrm{Au}-$ gusta Rodina (240 dzieł), Berthy Morissot (183 obrazy, akwarele i rysunki), Paula Cézanne'a (56 obrazów i rysunków z trzech kolekcji, dostępnych wcześniej osobno w różnych miejscach w Paryżu).

${ }^{13}$ Po raz pierwszy wydano tę korespondencję drukiem w 1952 r. (Rilke, Briefe über Cézanne). Jest zatem równie prawdopodobne, że albo Wickenburg poznał jakąś część treści/tematyki tych listów zimą 1907 r. (był z Rilkem blisko), albo ten komentarz jest efektem lektury Briefe über Cézanne, a więc tekst powstał nieco później, niż przypuszcza Kerstin Jesse.

${ }^{14}$ Polska edycja: Rilke, Cézanne. Ostatnie osobne wydanie tej części listów do żony wraz z zestawieniem odpowiednich obrazów Cézanne'a zob. Schirmer. 
Jesiennym $^{15}$. Skupienie uwagi na Modersohn-Becker łączy płynnie sąsiednie strony zapisków Wickenburga poświęcone Boznańskiej i Rilkemu.

Trzecim argumentem przemawiającym za znajomością artystek jest to, że najpierw w czasie kilkumiesięcznych pobytów Becker w Paryżu (1900, 1905) artystki mieszkały bardzo blisko siebie, mniej niż o kwadrans spacerem. W 1906 r. zaś mieszkały w jednym domu, właśnie przy bulwarze Monteparnasse 49, gdzie mieściła się też Académie Vitti (z którą także obie były związane - choć nie w tym samym czasie, bo Boznańska zaczęła tam uczyć dopiero w 1908 r.). Zachowane listy Mordersohn-Becker pozwalają określić, że z pewnością mieszkała pod tym adresem 1 grudnia $1906 \mathrm{r}$. Zapewne wprowadziła się wcześniej, czego jednak nie daje się precyzyjnie określić, można jedynie wskazać przedział czasowy, brak bowiem listów od 21 sierpnia - do 1 grudnia tegoż roku (Modersohn-Becker 410-411). Wyprowadziła się, jak wspomniano, około 29 marca 1907 r. Mieszkały więc w sąsiedztwie minimum cztery, a maksymalnie nawet siedem miesięcy. Czy wykorzystały tę sposobność, jak napisał Wickenburg, dla nawiązania jakichś bliższych lub przyjacielskich kontaktów? Nie wiadomo, ale zapewne się spotykały w przestrzeniach wspólnych nieistniejącego już budynku - obie przecież na stałe mieszkały w swoich pracowniach.

Obrazy Boznańskiej i Becker na pierwszy rzut oka łączy tylko figuralność, poza tym wyznacznikiem plastycznie i, jeśli można tak powiedzieć, antropologicznie są odmienne. Przede wszystkim skrajnie różnią się sposobem kładzenia farb i stosunkiem do cielesności. Boznańska, zakrywająca siebie i modelki, jak tylko można ${ }^{16}$, i Becker, która portretując się w Gauguinowskiej formie (il. 4), obnażyła nie tylko ciało anonimowej kobiety z prymitywnego ludu, ale samą siebie, cywilizowaną Europejkę, karmiącą dziecko po porodzie, przekroczyła tabu.

Są jednak między nimi także zbieżności, na płaszczyźnie egzystencjalnej $i$ artystycznej stawały przed tymi samymi dylematami. Obie szukały świadomie niezależności czego podstawą materialną było oparcie finansowe w ojcach. Ich niezależność artystyczna oparta była na wytrwałym dążeniu do zawodowego uprawiania malarstwa, co marginalizowało, a może nawet deprecjonowało je społecznie. Obie, wątpiąc, rozważały sens założenia rodziny i macierzyństwa, miały skomplikowane relacje z mężczyznami. Boznańskiej dłużej pomagał ojciec, odziedziczyła niewielki majątek rodzinny, nie wyszła za mąż, mimo wieloletnich zabiegów starających się o jej rękę artystów (Sos-

\footnotetext{
${ }^{15}$ P. Modersohn-Becker do R. M. Rilke, Worpswede 5.04.1907 (Modersohn-Becker 418-419).

${ }^{16} \mathrm{O}$ cielesności Boznańskiej zob. Sosnowska, Poza kanonem.
} 
nowska, „Zła matka”). Becker, pozbawiona środków do życia po wczesnej śmierci ojca, wyszła za mąż - za dużo starszego artystę, który dając jej zabezpieczenie materialne, nie ograniczał swobody w codziennym życiu. Wcześniej wielokrotnie dyskutowała najpierw z przyjaciółką, rzeźbiarką Clarą Westhoff, a następnie z Rilkem sens zakładania rodziny przez artystkę/artystę, posiadania dzieci, jako naturalnego ludzkiego pragnienia wobec nieuniknionej, niezbędnej samotności twórcy ${ }^{17}$. Po kilku latach burzliwego związku Becker uciekła od męża, postanowiła odzyskać tożsamość, wracając do panieńskiego nazwiska (o czym pisała w listach). Modersohn przyjechał jednak za nią do Paryża i po kilkumiesięcznych namowach skłonił ją do powrotu do Worpsede, gdzie wkrótce artystka urodziła córkę i zmarła na skutek powikłań okołoporodowych (20 grudnia 1907 r.).

Przy wszystkich różnicach formalnych dzieł obie artystki w sposób bardzo wyraźny łączą trzy tematy: portrety kobiet, portrety dzieci i portrety matek z dziećmi. Obie szukają wyjścia ze schematów „tematów kobiecych”. Te zagadnienia zasługują jednak na osobne rozważanie. Czy i na ile plastyczne refleksje, jakie w nich zawarły, ze sobą dialogują, czy w głębokich strukturach kompozycji mają jakieś paralelne elementy? Podobne w szukaniu plastycznego sensu reprezentacji innego niż tylko praca z/praca nad „powierzchnią” dzieła.

Syntetyczne wspomnienie Adolfa Wickenburga otwiera interesujący kontekst funkcjonowania recepcji malarstwa Olgi Boznańskiej, lokuje ją w dotąd wiązanych z jej osobą wysokich kręgach intelektualnych epoki. Niewątpliwie znajomość i zainteresowanie Victora Gebsattela o tym świadczy, choć dziś jest to zapoznany badacz i praktyk teorii postrzegania i pamięci zjawisk materialnych. Omawiane wspomnienie Wickenburga pozwala też dostrzec nową ścieżkę poszukiwań w paryskich kontaktach polskiej artystki, które pokazują jej związki z kręgiem kultury niemieckojęzycznej. Nawet jeśli nie jest to dróżka oczywista, to informacja o kontakcie Boznańskiej z Paulą Modersohn-Becker zasługuje na uwagę.

${ }^{17}$ Losy Rilkego i Clary Westhoff oraz ich córki także były zawikłane; dziecko wychowywali dziadkowie. O bardzo skomplikowanych relacjach emocjonalnych między Becker, Rilkem i Westhoff zob. Ososiński. 


\section{BIBLIOGRAFIA}

\section{ŹRÓDŁA}

Wickenburg, Alfred. Belvedere. Online-Werkkataloge: werkverzeichnisse.belvedere.at/online/279064/ alfred-wickenburg/biography. Dostęp 20.10.2020.

Wickenburg, Alfred. [Wspomnienia], Archiv Belvedere, Wien Schenkung aus Priwatbezitz: Alfred Wickenburg, AKB_VIN_15_D_14 [nlb.]

Modersohn-Becker, Paula. The Letters and Journals, red. i thum. Arthur S. Wensinger i Carole C. Hoey, Northwestern University Press, 1983, archive.org/details/paulamodersohnbe00mode/ page/n7/mode/2up. Dostęp 1.11.2020.

Listy E. Gebsattela do O. Boznańskiej, Dział Rękopisów Muzeum Narodowego w Krakowie, Archiwum Olgi Boznańskiej. Korespondencja od różnych osób, MNK VIII-rkps-1062/ 158/1-84.

\section{OPRACOWANIA}

Arno, Anna. Jaka szkoda. Krótkie życie Pauli Modersohn-Backer. Słowo/obraz, terytoria, 2015.

Bagińska, Agnieszka, U Olgi Boznańskiej. Oblicza pracowni artystki. Wydawnictwo MADO, 2013.

Bergson, Henri. Matière et mémoire. Essai sur la relation du corps à l'esprit, Paris, Alcan, 1896.

Beuys, Barbara. Paula Modersohn-Becker oder Wenn die Kunst das Leben ist. Insel-Verlag, 2009.

Bobrowska, Ewa. Olga Boznańska (1865-1940) [katalog wystawy w Muzeum Narodowym w Krakowie, kuratorki wystawy Ewa Bobrowska i Urszula Kozakowska-Zaucha, 25.10. 2014 - 01.02.2015], Muzeum Narodowe w Krakowie, 2014.

Buda, Oktavian. „Psychopatologie, Selbstbestimmung und Anthropologie - ein historischer Überblick", Noesis, 2012, ss. 1-18, noesis.crifst.ro/wp-content/uploads/revista/2012/2012 2_05.pdf. Dostęp 12.11.2020.

[Cézanne]. Catalogue des ouvrages de peinture, sculpture, dessin, gravure, architecture et art décoratif. Exposés au Petit Palais des Champs-Élysées, [Paris,] 1907, archive.org/details/ cataloguedesouvr00salo. Dostęp 29.10.2020.

Gebsattel, Viktor. Bemerkungen zur Psychologie der Gefühlsirradiation. Wilhelm Engelmann, 1907

Gebsattel, Viktor. Imago Hominis: Beiträge Zu Einer Personalen Anthropologie. Verlag Neues Forum, 1964. (Wyd. 2: O. Müller, 1968).

Higersberger, Renata. „W świetle lampy naftowej. Intymistyczne malarstwo Olgi Boznańskiej”. Olga Boznańska [katalog wystawy w Muzeum Narodowym w Warszawie, 26.02.2015 2.06.2015], red. merytoryczna Renata Higersberger, autorki scenariusza, kuratorki: Ewa Bobrowska i Urszula Kozakowska-Zaucha, Muzeum Narodowe w Warszawie, 2015, ss. $16-25$.

Knapowska-Niziołek, Magdalena. „Olga Boznańska - Frida za mgłą. Historia portretu pewnej enigmatycznej pianistki”. Niezła sztuka, niezlasztuka.net/o-sztuce/olga-boznanska-fridaza-mgla/. Dostęp 29.10.2020. 
Kudelska, Dorota. „Olga Boznańska w Wiedniu”. Veritas in caritate. Księga pamiątkowa ku czci Księdza Profesora Andrzeja Szostka MIC, red. Marcin Tkaczyk, Marzena Krupa i Krzysztof Jaworski, Wydawnictwo KUL, 2016, ss. 277-285.

Lawlor, Leonard. „Henri Bergson”. Stanford Encyclopedia of Philosophy (1. ed. May 18, 2004, substantive revision May 27, 2020), plato.stanford.edu/entries/bergson/. Dostęp 11.10. 2020.

Ososiński, Tomasz. „Listy do żony i nie tylko - korespondencja Rainera Marii Rilkego z Klarą Rilke-Westhoff". Listy Rainera Marii Rilkego do Klary Rilke-Westhoff, przeł. i oprac. Tomasz Ososiński. Słowo/obraz, terytoria, 2016, ss. 7-20.

Perry, Gillian. Paula Modersohn-Becker: Her life and work. Harper \& Row, 1979.

Perry, Gillian. Women artists and the Parisian avant-garde: Modernism and 'feminine' art 19001920s. Manchester University Press, 1995.

Rilke, Reiner Maria. Briefe über Cézanne. Insel-Verlag, 1952.

Rilke, Reiner Maria. Cézanne. Tłum. Andrzej Serafin, red. Monika Baranowska, Wydawnictwo Sic!, 2015.

Scheible, Burkhard S. Viktor Emil von Gebsattel (1883-1976). Leben und Werk Inaugural-Dissertation zur Erlangung des Doktorgrades der Medizin, PhD Dissertation: Institut für Ethik und Geschichte der Medizin der Universität Tübingen, https://ub01.uni-tuebingen.de/ xmlui/bitstream/handle/10900/45220/pdf/Druckversion2008_04_20.pdf?sequence=1\&isA llowed=y. Dostęp 20.10.2020.

Schirmer, Lothar. Paul Cézanne - die Bilder seiner Ausstellung Paris 1907: 57 Gemälde und Aquarelle von Paul Cézanne und 33 Briefe von Rainer Maria Rilke. Rekonstruktion der Cézanne-Ausstellung im Grand Palais, oprac. Bettina Kaufmann, red. Lothar Schirmer. Schirmer/Mosel, 2018.

Sosnowska, Joanna. Poza kanonem. Sztuka polskich artystek 1880-1939, Instytut Sztuki PAN, 2003.

Sosnowska, Joanna. „Zła matka”. Zeszyty Naukowo-Artystyczne. Wydziat Malarstwa Akademii Sztuk Pięknych w Krakowie, nr 7, 2006, ss. 29-36, zeszyty.asp.krakow.pl/wp-content/ uploads/2014/12/Zeszyt_Malarstwa_7.pdf. Dostęp 20.10.2020.

Rollig, Stella, i Kerstin Jesse, redaktorzy. Alfred Wickenburg - Visionen in Farbe und Form. Belvedere, 2017.

Rollig, Stella, Christian Huemer i Agnes Husslein-Arco, redaktorzy. Alfred Wickenburg: monograph and catalogue raisonné. Tłum. Laura Freeburn i in. Belvedere, Ritter Verlag, 2018.

Zbierzchowski, Henryk. „Z pracowni artystów polskich w Paryżu. Boznańska i Muttermilchowa”. Tygodnik Ilustrowany, nr 40, 1910, ss. 804.

\section{GOŚCIE W PRACOWNI OLGI BOZNAŃSKIEJ: \\ VIKTOR E. VON GEBSATTELI I ALFRED WICKENBURG Z PAULĄ MORDERSOHN-BACKER W POBLIŻU}

\section{Streszczenie}

Alfred Wickenburg w niepublikowanych Wspomnieniach krótko opisuje wizytę w pracowni Olgi Boznańskiej (1907), gdzie przyprowadził go Vincent E. Gebsattel, pionier teorii percepcji opartej o korelację czasu i pamięci oraz analizę wrażeń estetycznych. Gebsattel był zafascynowany twórczością malarki, która pojawia się w tekście wśród takich postaci, jak Kessler, Vollard, Gide, 
Bonnard, Rodin, Rilke. Wickenburg wspomina o zwiedzaniu wystawy Cézanna z Rilkem, a także o szczególnej roli Pauli Modersohn-Becker, która była przewodnikiem poety po wcześniejszych wystawach mistrza. Przy tej okazji wzmiankuje, że Boznańska przyjaźniła się z Becker, o czym nie ma mowy w literaturze przedmiotu. Ustaliłam, że malarki mieszkały na przełomie 1906/1907 przy Montparnasse 49. Nie wiadomo, czy się przyjaźniły, ale ich kontakt w drodze do mieszkańpracowni jest prawdopodobny. $Z$ dokumentów Becker wynika, że na pewno miały na to cztery, a być może nawet siedem miesięcy.

Wspomnienia Wickenburga są jednym z wielu przykładów niedocenianych kontaktów artystycznych i intelektualnych Boznańskiej spoza kręgu polsko-francuskiego.

Słowa kluczowe: Olga Boznańska; Paula Modersohn-Becker; Vincent E. Gebsattel; Adolf Wickenburg.

\author{
GUESTS AT OLGA BOZNAŃSKA'S STUDIO: \\ VIKTOR E. VON GEBSATTEL AND ALFRED WICKENBURG, \\ WITH PAULA MORDERSOHN-BECKER ALSO NEARBY
}

\title{
S u m m a ry
}

Alfred Wickenburg, in his unpublished Memoirs, briefly describes a visit to Olga Boznańska's studio in 1907, where he was brought by Vincent E. Gebsattel, the pioneer of the theory of perception based on the correlation of time and memory and an analysis of aesthetic impressions, and who was fascinated by her work. Boznańska is presented in the text among such figures as Kessler, Vollard, Gide, Bonnard, Rodin and Rilke. Wickenburg mentions his visiting Cézanne's exhibition with Rilke, and the special role played by Paula Modersohn-Becker, who was Rilke's guide to Cézanne's earlier exhibitions. He also suggests that Boznańska was befriended by ModersohnBecker, a fact not mentioned in any of the literature on the subject. I have established, however, that the two woman painters lived in the same building at Montparnasse 49 at the turn of 1906/1907. It is not known whether they were friends, but their contact with each other seems probable. It can be inferred from Modersohn-Becker's own papers that this possibility existed for a period of at least four months, and maybe for as long as seven.

Wickenburg's Memoirs are one example of Boznańska's undervalued artistic and intellectual contacts outside of the Polish-French circle.

Keywords: Olga Boznańska; Paula Modersohn-Becker; Vincent E. Gebsattel; Adolf Wickenburg. 


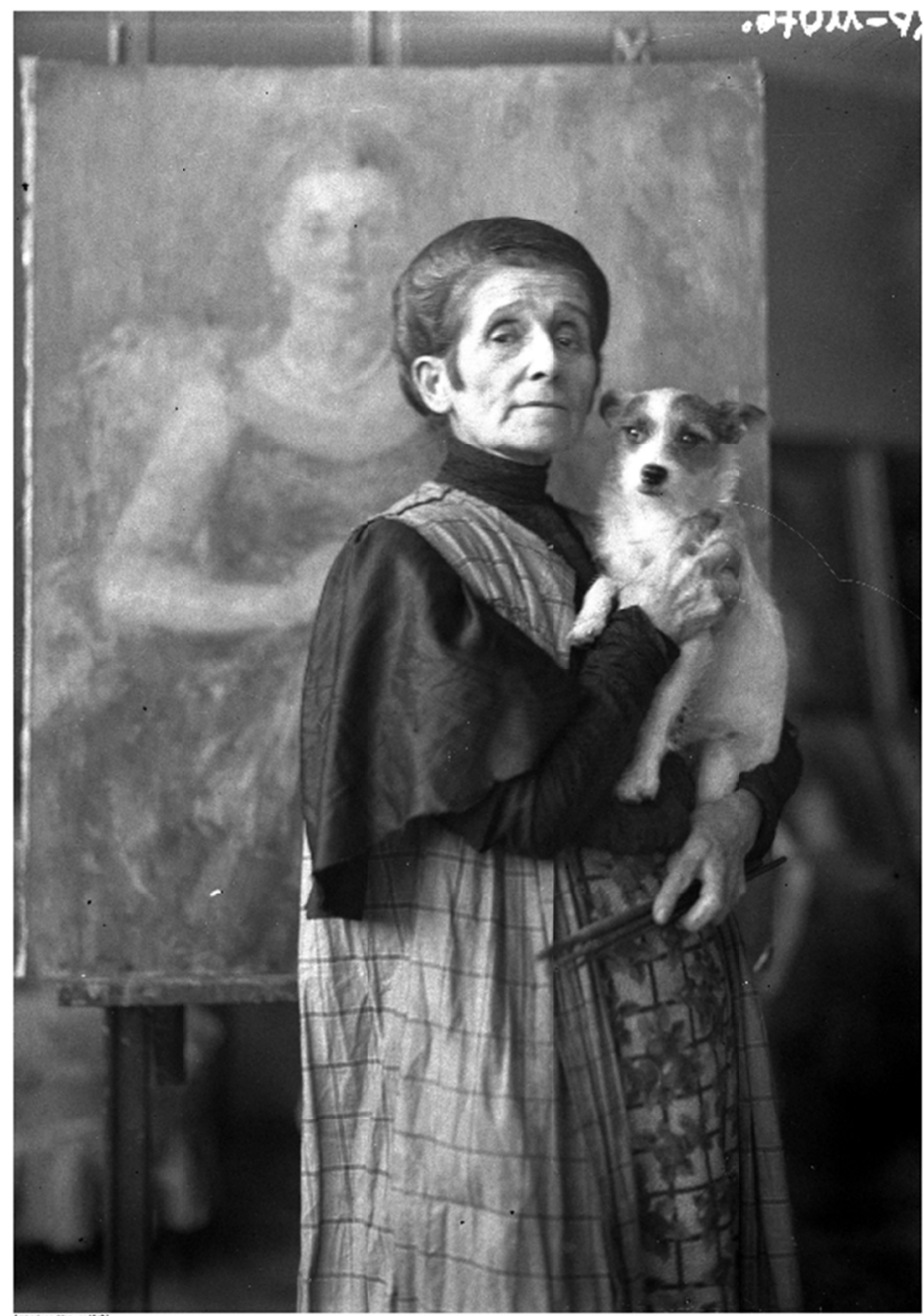

1. Olga Boznańska w paryskiej pracowni, fot. ok. 1930, Zespół: Koncern Ilustrowany Kurier Codzienny - Archiwum Ilustracji, Narodowe Archiwum Cyfrowe. Wikimedia Commons, commons.wikimedia.org/wiki/File:

Olga_Bozna\%C5\%84ska.png. Dostęp 23.03.2021. 


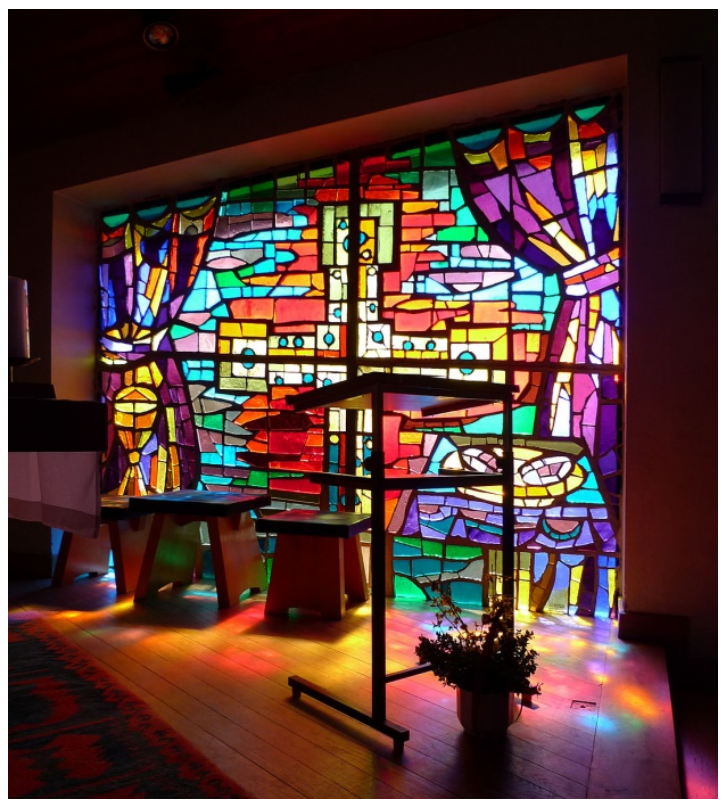

2. Adolf Wickenburg, Projekt - realizacja, Privatsammlung- Rut-und Klaus-Bahlsen-Stiftung, Niedersächsisches Landesmuseum Hannover.

Wikimedia Commons, commons.wikimedia.org/wiki/File:ModersohnBecker_(5)Selbstbildn_m_Bl\%C3\%BCtenkranz.JPG. Dostęp 23.03.2021

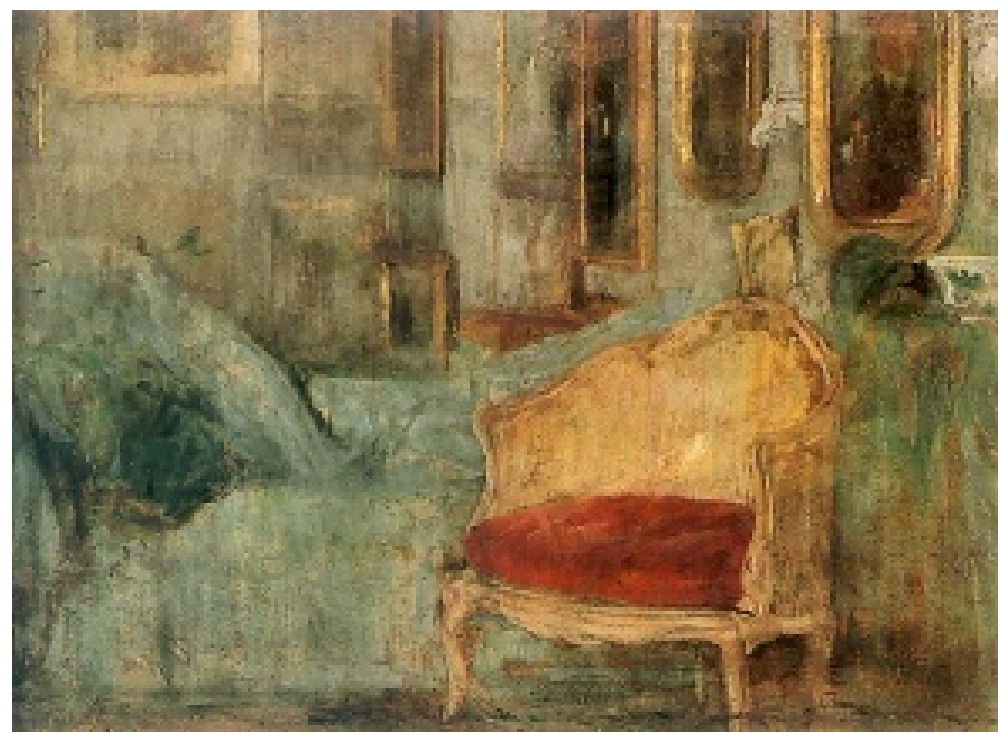

3. Olga Boznańska, Wnętrze paryskiej pracowni, 1908, olej, tektura $50 \times 71.5 \mathrm{~cm}$, Muzeum Narodowe w Krakowie, pinakoteka.zascianek.pl.

Wikimedia Commons, commons.wikimedia.org/wiki/File:Olga_Bozna\%C5\%84ska. Dostęp 23.03.2021. 


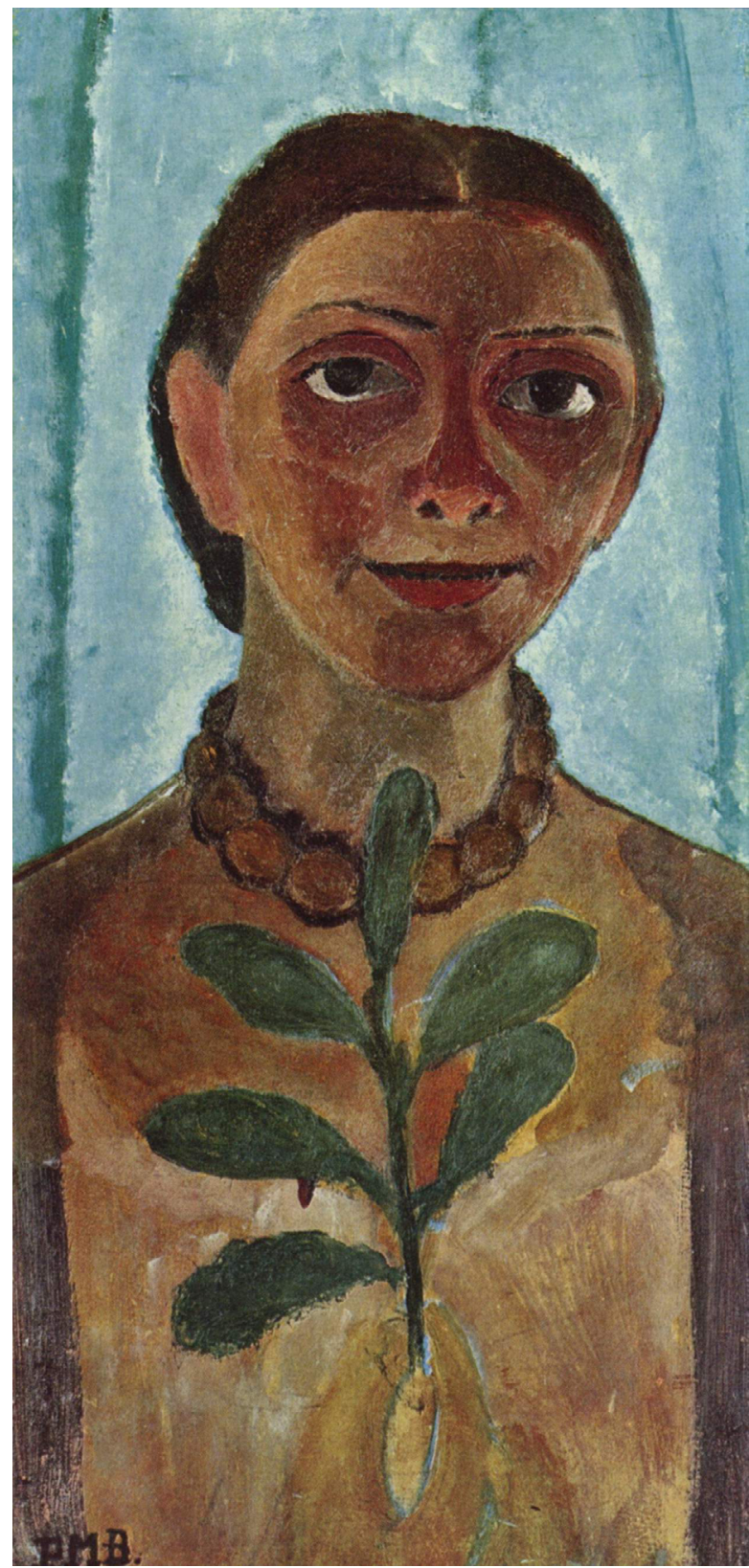

4. Paula Modersohn-Becker, Malarz z gatazka kamelii (autoportret), 1907, olej, deska $62 \times 31 \mathrm{~cm}$, Museum Folkwang, Essen, The Yorck Project (2002) 10.000 Meisterwerke der Malerei (DVD-ROM), distributed by DIRECTMEDIA Publishing GmbH. Wikimedia Commons, commons.wikimedia.org/wiki/File:Paula_Modersohn-Becker_006.jpg. Dostęp 23.03.2021. 